\title{
A STUDY OF HISTOLOGICAL PATTERNS OF ENDOMETRIUM IN ABNORMAL UTERINE BLEEDING
}

\author{
Anureet Kaur ${ }^{1}$, Shivani Jindal2, Puneet Kaur ${ }^{3}$ \\ 1 Professor, Department of Pathology, Adesh Medical College and Hospital, Mohri, Shahabad Markanda, Haryana. \\ ${ }^{2}$ Associate Professor, Department of Pathology, Adesh Medical College and Hospital, Mohri, Shahabad Markanda, Haryana. \\ ${ }^{3}$ Associate Professor, Department of Pathology, Adesh Medical College and Hospital, Mohri, Shahabad Markanda, Haryana.
}

\section{ABSTRACT}

\section{BACKGROUND}

Abnormal uterine bleeding (AUB) is defined as a pattern of bleeding that does not correspond with the duration, amount and frequency of the flow of a normal menstrual cycle. It is one of the most common problems among patients presenting to Gynaecologists. There are a variety of causes leading to AUB, ranging from hormonal imbalance in young women in the reproductive age group to hyperplasia and malignancies in perimenopausal and postmenopausal patients. Analysis of endometrial biopsies by histopathology provides insight into cause of such bleeding and is important for diagnosis as a relatively less invasive procedure.

Aims and Objectives- This study aims at histopathological analysis and at studying various patterns encountered in endometrial biopsies done for abnormal uterine bleeding in patients.

\section{MATERIALS AND METHODS}

This study includes all patients who underwent endometrial biopsy for abnormal bleeding (other than for evaluation for infertility) from September 2016 to September 2017 after satisfying the specific inclusion and exclusion criteria. The biopsy specimens were obtained by Dilatation and Curettage or by biopsy and sent for histopathological examination.

\section{RESULTS}

A total of 71 biopsy specimens were selected of which $43(60.5 \%)$ patients were premenopausal, 17 (23.9\%) were perimenopausal and $11(15.4 \%)$ were postmenopausal. Menorrhagia was the most common presenting complaint in 31 (43.6\%) patients with AUB. Most common findings on histopathological examination were as follows: Secretory endometrium in 22 (30.9\%), Proliferative endometrium in 14 (19.7\%), Disordered Proliferative Endometrium in 11 (15.4\%) patients followed by other patterns. Endometrial carcinoma was seen in $1(1.2 \%)$ patient.

\section{CONCLUSION}

Study of endometrial histopathology in abnormal uterine bleeding is helpful and important to diagnose various disorders including hyperplasia and carcinoma of endometrium.

\section{KEYWORDS}

Abnormal Uterine Bleeding, Postmenopausal Bleeding, Endometrial Hyperplasia, Secretory Phase Endometrium, Proliferative Phase Endometrium, Endometrial Carcinoma.

HOW TO CITE THIS ARTICLE: Kaur A, Jindal S, Kaur P. A study of histological patterns of endometrium in abnormal uterine bleeding. J. Evolution Med. Dent. Sci. 2017;6(88):6090-6093, DOI: 10.14260/jemds/2017/1323

\section{BACKGROUND}

Abnormal Uterine Bleeding (AUB) is an important symptom of both benign and serious gynaecological disease.[1] AUB in reproductive age women is defined as bleeding at abnormal or unexpected times or by excessive flow at the time of an expected menses. The aetiology of abnormal genital bleeding encompasses a wide range of disorders that can be secondary to anatomic changes of female genital tract, infection, endocrinologic disorders, malignancies, systemic illness. ${ }^{[2]}$

The most probable aetiology of abnormal uterine bleeding is related to patient's reproductive age, whether the patient is premenopausal, perimenopausal or postmenopausal..[3]

'Financial or Other Competing Interest': None.

Submission 12-10-2017, Peer Review 28-10-2017,

Acceptance 30-10-2017, Published 06-11-2017.

Corresponding Author:

Dr. Shivani Jindal,

B8/102, Nirmal Chhaya Towers,

VIP Road, Zirakpur, Punjab.

E-mail: shivanijindal2015@gmail.com

DOI: $10.14260 /$ jemds $/ 2017 / 1323$

\section{(c) $(1) \odot$}

Excessive menstrual blood loss affects $10-30 \%$ of menstruating women and in the order of $70 \%$ of all gynaecological consultations in the Perimenopause and Postmenopause. Perimenopause or menopausal transition is the phase, preceding the onset of menopause, at around 40 years of age, when the regular menstrual cycle of a woman changes from normal ovulatory cycles to a pattern of irregular cycles.[4] It includes a period of about 4-5 years before menopause, sometimes even several months, characterised by varying degrees of somatic and psychological changes that reflect the change in the ovarian cycle.[5] In premenopausal women, with normal findings on physical examination, the most likely diagnosis is DUB secondary to anovulation and in postmenopausal females, uterine pathology, especially endometrial carcinoma is a common cause of DUB.[3] Abnormal perimenopausal or postmenopausal bleeding is associated with endometrial carcinoma in approximately $10 \%$ of cases.[6,7] Endometrial biopsy by Dilatation and Curettage is considered the gold standard in AUB. The present study is designed to study the histopathological results of the endometrial biopsy in women with abnormal uterine bleeding. 


\section{Aims and Objectives}

This study aims at histopathological analysis and studying various patterns encountered in endometrial biopsies done for patients presenting with abnormal uterine bleeding.

\section{MATERIALS AND METHODS}

This is a retrospective descriptive study, carried out in the Department of Pathology, Adesh Medical College \& Hospital, Shahabad (M). The period of study was from September 2016 to September 2017 and the study included endometrial tissue obtained by Dilatation and curettage or biopsy done on patients with abnormal uterine bleeding.

A structured proforma was used to collect the medical history, examination findings of the patients, results of routine laboratory investigations and ultrasonography findings wherever available. Endometrial biopsy was done irrespective of endometrial thickness. Patients were categorised into reproductive $(<40$ yrs.) age groups, perimenopausal group ( $41-50 \mathrm{yrs}$.) and postmenopausal $>50$ yrs.). The endometrial tissue obtained was collected in $10 \%$ formal saline and sent for histopathological examination. Routine histopathological processing was done followed by embedding tissue in paraffin and 3-4 $\mu$ thick sections were prepared. Sections were stained with Haematoxylin and Eosin (H\&E) stain.

\section{RESULTS}

There were total of 71 biopsies from patients with abnormal uterine bleeding. Out of these, 43 (60.5\%) were premenopausal patients $(<40$ yrs.), 17 (23.9\%) were perimenopausal and $11(15.4 \%)$ were postmenopausal patients. The age of patients ranged from 21 to 70 years, and majority $(27,38 \%)$ of them were in $31-40$ years age group (mean age of $39.6 \mathrm{yrs}$.).

\begin{tabular}{|c|c|c|}
\hline $\begin{array}{c}\text { Age Group } \\
\text { (years) }\end{array}$ & $\begin{array}{c}\text { Number of } \\
\text { Patients }\end{array}$ & Percentage (\%) \\
\hline $21-30$ & 16 & 22.5 \\
\hline $31-40$ & 27 & 38.0 \\
\hline $41-50$ & 17 & 23.9 \\
\hline $51-60$ & 08 & 11.2 \\
\hline $61-70$ & 03 & 4.2 \\
\hline Total & 71 & 100 \\
\hline \multicolumn{3}{|c|}{$\begin{array}{c}\text { Table 1. Age Distribution of all Patients with Abnormal } \\
\text { Uterine Bleeding }\end{array}$} \\
\hline
\end{tabular}

\begin{tabular}{|c|c|c|}
\hline Pattern of Bleeding & No. of Patients & (\%) \\
\hline Menometrorrhagia & 17 & 23.9 \\
\hline Menorrhagia & 31 & 43.6 \\
\hline Bleeding per vaginum & 07 & 9.8 \\
\hline Postmenopausal bleeding & 10 & 14 \\
\hline Metrorrhagia & 00 & 00 \\
\hline $\begin{array}{c}\text { Discharge and Bleeding per } \\
\text { vaginum }\end{array}$ & 02 & 2.8 \\
\hline Polymenorrhoea & 04 & 5.6 \\
\hline \multicolumn{2}{|c|}{ Total } & $\mathbf{1 0 0 \%}$ \\
\hline Table 2. Distribution of Patients According to \\
Bleeding Pattern \\
\hline
\end{tabular}

Table 2 shows distribution of patients according to the type of complaints at time of presentation to the Gynaecology
OPD. Among all patients, menorrhagia was the most common bleeding pattern in our study. It was seen in $31(43.6 \%)$ patients followed by menometrorrhagia in 17 (23.9\%) patients. Other complaints recorded were bleeding per vaginum, polymenorrhoea, discharge with bleeding per vaginum. Among premenopausal patients, the commonest complaint was of menorrhagia reported in 28 out of 43 (65.1\%), while menometrorrhagia was the most common bleeding pattern noted in perimenopausal age group, in 8 out of $17(47 \%)$ patients. Postmenopausal bleeding was the next common pattern seen in $10(14 \%)$ patients.

\begin{tabular}{|c|c|c|}
\hline Histopathological Diagnosis & $\begin{array}{c}\text { No. of } \\
\text { Patients }\end{array}$ & (\%) \\
\hline Proliferative phase & 14 & 19.7 \\
\hline Secretory phase & 22 & 30.9 \\
\hline Simple hyperplasia with atypia & 01 & 1.4 \\
\hline $\begin{array}{c}\text { Complex hyperplasia with } \\
\text { atypia }\end{array}$ & 02 & 2.8 \\
\hline Atrophic endometrium & 01 & 1.4 \\
\hline $\begin{array}{c}\text { Disordered proliferative } \\
\text { endometrium }\end{array}$ & 11 & 15.4 \\
\hline Benign endometrial polyp & 01 & 1.4 \\
\hline $\begin{array}{l}\text { Extensive breakdown, dating } \\
\text { not possible }\end{array}$ & 03 & 4.2 \\
\hline Chronic Endometritis & 01 & 1.4 \\
\hline Endometrial carcinoma & 01 & 1.4 \\
\hline $\begin{array}{c}\text { Progesterone effect } \\
\text { endometrium }\end{array}$ & 04 & 5.6 \\
\hline Decidua only, no chorionic villi & 02 & 2.8 \\
\hline Products of Conception & 03 & 4.2 \\
\hline Inadequate & 05 & 07 \\
\hline Total & 71 & 100 \\
\hline
\end{tabular}

Of all the 71 patients who underwent histopathological examination of endometrial tissue, the most common finding was secretory phase, seen in $22(30.9 \%)$ patients, followed by proliferative phase in $14(19.7 \%)$ patients. Five (7\%) patients' biopsies were designated as inadequate for opinion. Disordered proliferative endometrium was seen in 11 (15.4\%) patients, $01(1.4 \%)$ showed simple hyperplasia with atypia, $02(2.8 \%)$ were complex hyperplasia with atypia, Hormone effect endometrium was seen in 04 (5.6\%) and Products of conception were present in 03 (4.2\%). However, only decidua was present in $02(2.8 \%)$, but no chorionic villi were present. Endometrial tissue undergoing extensive breakdown was seen in $03(4.2 \%)$ therefore, no opinion was possible in these cases. Benign endometrial polyp, Atrophic endometrium and chronic endometritis were seen in 01 (1.4\%) each.

\begin{tabular}{|c|c|c|c|c|c|c|}
\hline $\begin{array}{c}\text { Histo- } \\
\text { pathological } \\
\text { Diagnosis }\end{array}$ & $\begin{array}{c}\mathbf{2 1 - 3 0} \\
\mathbf{( \% )}\end{array}$ & $\begin{array}{c}\mathbf{3 1 - 4 0} \\
\mathbf{( \% )}\end{array}$ & $\begin{array}{c}\mathbf{4 1 - 5 0} \\
(\%)\end{array}$ & $\begin{array}{c}\mathbf{5 1 - 6 0} \\
\mathbf{( \% )}\end{array}$ & $\begin{array}{c}\mathbf{6 1 - 7 0} \\
\mathbf{( \% )}\end{array}$ & Total \\
\hline $\begin{array}{c}\text { Proliferative } \\
\text { phase }\end{array}$ & - & $5(7.0)$ & $7(41.1)$ & $2(25)$ & - & 14 \\
\hline $\begin{array}{c}\text { Secretory } \\
\text { phase }\end{array}$ & 10 & 10 & 2 & - & - & 22 \\
\hline $\begin{array}{c}\text { Simple } \\
\text { hyperplasia } \\
\text { with atypia }\end{array}$ & - & $1(3.5)$ & - & - & - & 01 \\
\hline $\begin{array}{c}\text { Complex } \\
\text { hyperplasia }\end{array}$ & - & $\begin{array}{c}1 \\
(35.7)\end{array}$ & - & $\begin{array}{c}11.7) \\
(12.5)\end{array}$ & - & 02 \\
\hline
\end{tabular}




\begin{tabular}{|c|c|c|c|c|c|c|}
\hline with atypia & & & & & & \\
\hline $\begin{array}{c}\text { Atrophic } \\
\text { endometrium }\end{array}$ & - & $1(3.5)$ & - & - & - & 01 \\
\hline $\begin{array}{c}\text { Disordered } \\
\text { proliferative } \\
\text { endometrium }\end{array}$ & $\begin{array}{c}1 \\
(1.4)\end{array}$ & $\begin{array}{c}5 \\
(7.0)\end{array}$ & $\begin{array}{c}4 \\
(23.5)\end{array}$ & $\begin{array}{c}1 \\
(12.5)\end{array}$ & - & 11 \\
\hline $\begin{array}{c}\text { Benign } \\
\text { endometrial } \\
\text { polyp } \\
\end{array}$ & - & - & - & $\begin{array}{c}1 \\
(12.5)\end{array}$ & - & 01 \\
\hline $\begin{array}{c}\text { Extensive } \\
\text { breakdown, } \\
\text { dating not } \\
\text { possible }\end{array}$ & - & $\begin{array}{c}2 \\
(7.1)\end{array}$ & $\begin{array}{c}1 \\
(5.2)\end{array}$ & - & - & 03 \\
\hline $\begin{array}{c}\text { Chronic } \\
\text { Endometritis }\end{array}$ & - & - & - & - & $\begin{array}{c}1 \\
(33.3) \\
\end{array}$ & 01 \\
\hline $\begin{array}{c}\text { Endometrial } \\
\text { carcinoma }\end{array}$ & - & - & - & - & $\begin{array}{c}1 \\
(33.3)\end{array}$ & 01 \\
\hline $\begin{array}{l}\text { Progesterone } \\
\text { effect } \\
\text { endometrium }\end{array}$ & $\begin{array}{c}1 \\
(1.4)\end{array}$ & $\begin{array}{c}1 \\
(3.5)\end{array}$ & $\begin{array}{c}2 \\
(10.5)\end{array}$ & - & - & 04 \\
\hline $\begin{array}{c}\text { Decidua only, } \\
\text { no chorionic } \\
\text { villi } \\
\end{array}$ & - & $\begin{array}{c}1 \\
(3.5)\end{array}$ & $\begin{array}{c}1 \\
(5.2)\end{array}$ & - & - & 02 \\
\hline $\begin{array}{l}\text { Products of } \\
\text { Conception }\end{array}$ & $\begin{array}{c}3 \\
(18.5) \\
\end{array}$ & - & - & - & - & 03 \\
\hline Inadequate & $\begin{array}{c}1 \\
(1.4)\end{array}$ & - & - & $\begin{array}{c}3 \\
(37.5)\end{array}$ & $\begin{array}{c}1 \\
(33.3)\end{array}$ & 05 \\
\hline Total & 16 & 27 & 17 & 8 & 3 & 71 \\
\hline
\end{tabular}

In different histological patterns witnessed when considering age wise distribution, as shown in Table 4, maximum number of patients $(7,50 \%)$ with proliferative endometrium were in 41-50 years, whereas secretory endometrium was present in $10(45.4 \%)$ patients each in 2130 years and 31-40 years. Disordered proliferation was seen in equal distribution in 31-40 years and 41-50 years with 5 (45.4\%) each. Chronic endometritis and endometrial carcinoma were seen in 61-70 years. Similarly, maximum number of inadequate biopsies were reported in same group in patients where scanty endometrial tissue was obtained and curettings mostly contained haemorrhage, fibrinous exudates and inflammatory cells as in pyometra.

\section{DISCUSSION}

Abnormal uterine bleeding can be caused by a wide variety of disorders. The bleeding could be a sign of an underlying localised condition including benign tumours, malignancy and infection. Endometrial cancer and hyperplasia are likely causes of abnormal bleeding in perimenopausal and postmenopausal bleeding. ${ }^{[8]}$

With regards to age of the study population, patients' age ranged from 21 to 70 years (mean age 39.6\%). Maximum number of patients were seen in 31-40 years age group (27, $38 \%$ ). Hoxhaj et al also reported maximum number of patients in same age group followed by 41-50 years age group.[8] In perimenopausal age group, there were 17 $(23.9 \%)$ patients. Whereas varying number of patients $(33.5 \%, 36 \%, 38 \%, 37.9 \%)$ have been reported to present in perimenopausal age with abnormal uterine bleeding. ${ }^{[9,10,11,12]}$

\section{Pattern of Bleeding}

With regards to the pattern of bleeding, the commonest complaint was menorrhagia, reported in 31 (43.6\%) patients, followed by menometrorrhagia in 17 (23.9\%) of all patients. Hoxhaj et al, Kaur et al also reported menorrhagia as the commonest complaint among all patients (44\%).[8,10] Jetley et al also found menorrhagia as a leading complaint in $46.45 \%$, followed by metrorrhagia in $20 \%$ of their study group patients.[13] However, Moghal et al found metrorrhagia in majority of their patients (48\%), followed by menorrhagia in $41 \%$ of all patients.[14]

Among premenopausal patients, the commonest complaint was of menorrhagia reported in 28 out of 43 (65.1\%). Menometrorrhagia was the most common bleeding pattern noted in perimenopausal age group, in 8 out of 17 (47\%) patients. Among perimenopausal patients, main complaint was menorrhagia. In a study by Bhosle et al (2010), menorrhagia was seen in $53.3 \%$ patients, followed by $28.2 \%, \quad 12.2 \%$ and $6.5 \%$ with polymenorrhagia, intermenstrual bleeding and metrorrhagia respectively. ${ }^{[4]}$ In another study by Cornitescu, maximum number of patients had menometrorrhagia (34\%).[5]

In our study, Postmenopausal bleeding was the cause of evaluation in $10(14 \%)$ patients. Moghal et al reported 6.5\% patients with postmenopausal bleeding. ${ }^{[14]}$ Kaur et al reported the same in $12 \%$ patients.[10]

\section{Histopathological Diagnosis}

In our study, the most common finding was secretory phase, seen in 22 (30.9\%) patients, as also seen by Hoxhaj et al, Jetley et al, Moghal et al and Vaidya et al in 29\%, 32.4\% and $25.3 \%$ and $29.6 \%$ patients respectively.[8,13,14,15]

Proliferative phase in $14(19.7 \%)$ patients was the second commonest histological pattern observed in this study. Jetley et al, Hoxhaj et al, Vaidya et al reported similar findings in $30.5 \%, 55 \%, 24 \%$ patients. $[13,8,15]$

We found disordered proliferative endometrium in 11 $(15.4 \%)$ patients. However, a varying range from $6.8 \%$ to $17 \%$ has been reported in different studies. (Jetley et al, Hoxhaj et al, Vaidya et al).[13,8,15]

Hyperplasia of the endometrium was seen in $4.2 \%$ of all patients with AUB in our study. Of these, 1 (1.4\%) patient each of simple and complex hyperplasia with atypia was seen in 31-40 years age group while another one patient $(1.4 \%)$ with complex hyperplasia with atypia was in $6^{\text {th }}$ decade of life. Cornitescu et al reported $1.6 \%$ patients with complex hyperplasia with atypia,[5] incidence of hyperplasia was $10.92 \%$. In a study by Vaidya et al, simple hyperplasia without atypia was in $1.2 \%$ and complex hyperplasia with atypia was in $0.5 \%$ of all patients with abnormal uterine bleeding. ${ }^{[15]}$ In perimenopausal age group, varying incidence of hyperplasia has been reported in $1.2 \%$ to $17.8 \%$ to $78.26 \%$ in different studies by Cornitescu, Bhosle, Bharti et al.[5,4,16] However, in our study, none of these patients diagnosed with hyperplasia were in perimenopausal age group.

Benign endometrial polyp, Atrophic endometrium and chronic endometritis were seen in $01(1.4 \%)$ each in $6^{\text {th }}, 4^{\text {th }}$ and $7^{\text {th }}$ decade.

Among patients in 31-40 years age group, the most frequent finding was secretory endometrium in $35.7 \%$ patients, followed by disordered proliferative and proliferative phase endometrium in $7 \%$ patients each.

In perimenopausal age group (41-50 years), regarding histopathology of endometrium, in our study, proliferative endometrium (41.1) and disordered proliferative 
endometrium (23.5\%) along with secretory endometrium $(11.7 \%)$ were main findings. In comparison, Bharti et al reported $4.3 \%$ patients with proliferative endometrium while Bhosle et al found $66.1 \%$ proliferative endometrium in perimenopausal patients. [16, 4] Vaidya et al reported secretory endometrium, proliferative endometrium and disordered proliferative endometrium in $19.8 \%, 18.8 \%$ and $15 \%$ patients.[15] We did not find any case of hyperplastic endometrium or endometrial carcinoma in perimenopausal patients.

In perimenopausal age, in the absence of any organic lesion, abnormal uterine bleeding occurs due to hormonal imbalance resulting from abnormalities of hypothalamuspituitary-ovarian axis, leading to derangement of follicular maturation, ovulation, corpus luteum formation. Endometrial proliferation occurs in response to unopposed oestrogen, resulting in hyperplasia, polyp formation and is characterised by irregular painless excessive bleeding. ${ }^{[13]}$

Among patients $>50$ years of age, and in those with postmenopausal bleeding, proliferative endometrium was noted in 2 (25\%), chronic endometritis in 1 (33.3\%), Benign endometrial polyp in 1 (12.5\%), endometrial adenocarcinoma in $1(33.3 \%)$ patient. None of the patients were reported to have hyperplasia, atrophy, or hormone effect endometrium in this age group in our study. Bharti et al noted that $56 \%$ had simple hyperplasia without atypia, $8 \%$ had complex hyperplasia without atypia, $8 \%$ had complex hyperplasia with atypia, $16 \%$ had atrophic endometrium and $12 \%$ had carcinoma in postmenopausal patients.[16] Identification of hyperplasia is important as it is considered to be a precursor of endometrial carcinoma. In simple hyperplasia, normal gland to stroma ratio is maintained whereas in complex hyperplasia, there is an increased ratio of the same. Simple and complex hyperplasia are further subdivided into typical and atypical types depending on presence or absence of cytological atypia.[10]

In our study, endometrial carcinoma was found in a 63year-old lady who presented with postmenopausal bleeding. It has been reported in $2.48 \%$ of all patients with AUB by Vaidya et al and $2.0 \%$ by Desai et al.[15, 1] Endometrial carcinoma mostly occurs in elderly women (Sixth and seventh decade) with $90 \%$ of patients presenting with vaginal bleeding or discharge as a presenting complaint.[1]

\section{CONCLUSION}

Endometrial histopathology in abnormal uterine bleeding is an important tool to diagnose various endometrial patterns ranging from proliferative, secretory, simple and complex hyperplasia with/without atypia, disordered proliferation and atrophic endometrium, including pathologic conditions of uterus including hyperplasia and carcinoma of endometrium, especially in perimenopausal and postmenopausal bleeding. It offers benefits like ease and safety of obtaining samples, along with reasonable reporting time and diagnostic accuracy.[17]

\section{REFERENCES}

[1] Desai K, Patole KP, Kathaley M. Endometrial evaluation by histopathology in abnormal uterine bleeding in perimenopausal and postmenopausal patients. MVP Journal of Medical Sciences 2014;1(2):75-9.

[2] Goodman A. Abnormal genital tract bleeding. Clin Cornerstone 2000;3(1):25-35.

[3] Oriel KA, Schrager S. Abnormal uterine bleeding. Am Fam Physician 1999;60(5):1371-82.

[4] Bhosle A, Fonseca M. Evaluation and histopathological correlation of abnormal uterine bleeding in perimenopausal women. Bombay Hospital J 2010;52(1):69-72.

[5] Cornitescu Fl, Tanase F, Simionescu C, et al. Clinical, histopathological and therapeutic considerations in non-neoplastic abnormal uterine bleeding in menopause transition. Rom J Morphol Embryol 2011;52(3):759-65.

[6] Creasman WT. Endometrial cancer: incidence, prognostic factors, diagnosis and treatment. Semin Oncol 1997;24(1 Suppl 1):S1-140-S1-50.

[7] Smith-Bindman R, Kerlikowske K, Feldstein VA, et al. Endovaginal ultrasound to exclude endometrial cancer and other endometrial abnormalities. JAMA 1998;280(17):1510-7.

[8] Hoxhaj 0, Gjoni M. Histopathological pattern of endometrium in abnormal uterine bleeding. International Journal of Science and Research 2015;4(11):1783-5.

[9] Saraswathi D, Thanka J, Shalinee R, et al. Study of endometrial pathology in abnormal uterine bleeding. J Obstet Gynecol India 2011;61(4):424-30.

[10] Kaur P, Kaur A, Suri AK, et al. A two year histopathological study of endometrial biopsies in a teaching hospital in Northern India. Indian Journal of Pathology and Oncology 2016;3(3):508-19.

[11] Yusuf NW, Nadeem R, Yusf AW, et al. Dysfunctional uterine bleeding. A retrospective clinicopathological study over 2 years. Pak J Obstet Gynaecol 1996;9:2730.

[12] Mahapatra M, Mishra P. Clinicopathological evaluation of abnormal uterine bleeding. J Health Res Rev 2015;2(2):45-9.

[13] Jetley S, Rana S, Jirajpuri ZS. Morphological spectrum of endometrial pathology in middle-aged women with atypical uterine bleeding: a study of 219 cases. J Midlife Health 2013;4(4):216-20.

[14] Moghal N. Diagnostic value of endometrial curettage in abnormal uterine bleeding - a histopathological study. J Pak Med Assoc 1997;47(12):295-9.

[15] Vaidya S, Lakhey M, Vaidya S, et al. Histopathological pattern of abnormal uterine bleeding in endometrial biopsies. Nepal Med Coll J 2013;15(1):74-7.

[16] Bharti B, Satish PR. Feasibility and yield of endometrial biopsy using suction curette device for evaluation of abnormal pre and postmenopausal bleeding. J Obstet Gynecol India 2008;58(4):322-6.

[17] Munro MG, Critchley HO, Fraser IS, et al. The FIGO classification of causes of abnormal uterine bleeding in the reproductive years. Fertility and Sterility 2011;95(7):2204-8, 2208. e1-3. 